The FASEB Journal express article 10.1096/fj.00-0653fje. Published online January 19, 2001.

\title{
Protective effects of anti-C5a peptide antibodies in experimental sepsis
}

\author{
Markus S. Huber-Lang, ${ }^{*}$ J. Vidya Sarma, ${ }^{*}$ Stephanie R. McGuire, ${ }^{*}$ Kristina T. Lu, ${ }^{*}$ Ren Feng \\ Guo,* Vaishalee A. Padgaonkar,* Ellen M. Younkin,* Ines J. Laudes, ${ }^{*}$ Niels C. Riedemann,* \\ John G. Younger, ${ }^{\dagger}$ Peter A. Ward,* \\ *Department of Pathology, University of Michigan Medical School, Ann Arbor, Michigan, and \\ Department of Emergency Medicine, University of Michigan Medical School, Ann Arbor, \\ Michigan
}

Corresponding author: Peter A. Ward, Department of Pathology, The University of Michigan Medical School, 1301 Catherine Road, Ann Arbor, MI 48109-0602. E-mail: pward@umich.edu

\section{ABSTRACT}

We evaluated antibodies to different peptide regions of rat $\mathrm{C} 5 \mathrm{a}$ in the sepsis model of cecal ligation and puncture (CLP) for their protective effects in rats. Rabbit polyclonal antibodies were developed to the following peptide regions of rat C5a: amino-terminal region (A), residues 1-16; middle region $(\mathrm{M})$, residues 17-36; and the carboxyl-terminal region $(\mathrm{C})$, residues 58-77. With rat neutrophils, the chemotactic activity of rat $\mathrm{C} 5 \mathrm{a}$ was significantly inhibited by antibodies with the following rank order: anti-C > anti-M $>$ anti-A. In vivo, antibodies to the $\mathrm{M}$ and $\mathrm{C}$ (but not A) regions of C5a were protective in experimental sepsis, as determined by survival over a 10day period, in a dose-dependent manner. The relative protective efficacies of anti-C5a preparations (in descending order of efficacy) were anti-C $\geq$ anti-M $>$ anti-A. In CLP rats, a delay in infusion of antibodies, which were injected at 6 or $12 \mathrm{~h}$ after CLP, still resulted in significant improvement in survival rates. These in vivo and in vitro data suggest that there are optimal targets on C5a for blockade during sepsis and that delayed infusion of anti-C5a antibody until after onset of clinical evidence of sepsis still provides protective effects.

Key words: C5a $\bullet$ cecal ligation/puncture $\bullet$ neutrophils

I n severe cases of trauma and sepsis, homeostatic control of the coagulation, fibrinolytic, and complement systems is often lost (1-4). Injured or burned tissue, endotoxin, and cell membranes have all been shown to activate the complement system $(1,5,6,7)$ as defined by the appearance in plasma of complement activation products, especially C3a and C5a (1-5, 710). During experimental sepsis, uncontrolled generation of $\mathrm{C} 3 \mathrm{a}$ is associated with an immunosuppressive outcome affecting B-cell function, which leads to diminished production of antibodies (11). Excessive production of C5a causes neutrophil dysfunction with loss of bacterial killing (12), platelet activation (13), and direct or indirect microvascular damage (14). Similar to the increased levels of plasma complement activation products occurring in experimental sepsis, in patients with systemic inflammatory response syndrome (SIRS) and sepsis, increased plasma levels of C3a and C5a were correlated with adverse outcomes (2, 3, 9). C5a may be particularly important in the pathogenesis of sepsis-related complications, such as adult respiratory distress 
syndrome (ARDS), and multiorgan dysfunction syndrome (MODS) (15-18). In experimental sepsis (CLP), the absence of $\mathrm{C} 5$ ( $\mathrm{C}^{-1-}$ mutant mice) confers some protective effects in sepsis as defined by delays in mortality $(19,20)$. Evidence also indicates that administration of anti-C5a antibodies improves the hemodynamic and respiratory functional parameters in monkeys or pigs infused intravenously with large amounts of live bacteria or lipopolysaccharide (LPS) $(15,18)$.

In experimental sepsis studies, anti-C5a antibodies directed against the whole C5a molecule (21) or its conversion product $\mathrm{C} 5 \mathrm{a}_{\text {desarg }}(15,22)$ or against amino acids $57-74$ of human C5a $(18,23)$ were administered before induction of acute endotoxemia by infusion of LPS or live bacteria (15, 18, 21-23). Using the CLP-model of sepsis in rats, which mimics the pathophysiology of human sepsis very closely (24), we have recently demonstrated that administration of anti-C5a (directed against the $\mathrm{M}$ region of rat $\mathrm{C} 5 \mathrm{a}$ : residues 17-36) immediately after induction of sepsis resulted in a significant reduction in levels of bacteria and improvement in long-term survival (12). In the present investigation, we have determined whether antibodies targeted against other peptide regions of C5a (A peptide region: residues 1-16, and $\mathrm{C}$ peptide region: residues 58-77) also conferred protective effects. We also assessed if significant protective effects would occur when infusion of anti-C5a was considerably delayed after the onset of CLP-induced sepsis.

\section{MATERIALS AND METHODS}

\section{Reagents and chemicals}

All materials were obtained from Sigma Chemical Co. (St. Louis, Mo.) unless otherwise indicated. Recombinant rat $\mathrm{C5a}(\mathrm{rrC5a})$ was expressed in Sf9 insect cells. The recombinant C5a contains six alternating histidine and glutamine residues, at the amino terminus facilitating purification on a $\mathrm{Ni}^{2+}$ sepharose column. The rrat C5a was functionally active in the neutrophil chemotactic assay, with activity peaking between 10-100 nM (Huber-Lang M. S., Sarma V. J., Lu K. T., McGuire S. R., Padgaonkar V. A., Guo R. F., Younkin E. M., Czermak B. J., Kunkel R. G., Ding J., Erickson R., Curnutte J. T., and Ward P. A. Role of C5a in multi-organ failure; unpublished results).

\section{Preparation and characterization of antibodies against peptides of rat C5a}

Based on the Jameson Wolf antigenic index of the rat C5a molecule, the sequence KHRVPKKCCYDGARENKYET (M peptide region, corresponding to amino acid residues 1736) was chosen for antibody production (12). Additionally, the amino-terminal peptide DLQLLHQKVEEQAAKY (A peptide region, amino residues 1-16) and carboxyl-terminal peptide CTIADKIRKESHHKGMLLGR (C peptide region, amino residues 58-77) were selected for development of KLH-conjugates and immunization of rabbits (Fig. 1). After several immunizations, the antibodies were affinity-purified from serum by using the corresponding synthetic peptide (A, M, or C) coupled to sepharose beads. Peptide synthesis, antibody production, and antibody purification were done by Research Genetics, Inc., Huntsville, Ala.

\section{Western blot analysis of rrat C5a and human C5a}

For Western blot analysis, rrat C5a (200 ng) and rhuman C5a (200 ng) were loaded under reducing conditions onto a 15\% SDS PAGE. We performed electrophoresis and transferred 
proteins to a polyvinylidene fluoride membrane (Schleicher \& Schuell, Keene, N.H.) by using a semidry electrophoresis apparatus (LkB Multiphor II, Pharmacia Biotech, Uppsala, Sweden). The blot was incubated with 5\% milk for $1 \mathrm{~h}$ at RT and then probed with various rabbit anti-C5a peptide antibodies (at a final concentration of $3 \mu \mathrm{g} / \mathrm{ml}$ ) overnight at $4{ }^{\circ} \mathrm{C}$. After washing, an alkaline phosphatase-conjugated goat anti-rabbit IgG antibody (Ab) (Jackson ImmunoResearch, Inc., West Grove, Pa.) was used as a secondary Ab (1:1000) at RT for $1 \mathrm{~h}$, followed by an additional washing step and alkaline phosphatase substrate color development (Bio-Rad Laboratories, Hercules, Calif.) with care being taken to choose the same developing time (15 min) for each Western blot.

\section{Isolation of rat neutrophils}

Whole blood of control rats was drawn from the inferior cava vein into syringes containing 0.1 $\mathrm{ml} / \mathrm{ml}$ blood of anticoagulant ACD (Baxter Health Care, Deerfield, Ill.). Neutrophils were isolated by using Ficoll-Paque gradient centrifugation (Pharmacia Biotech AB) followed by a dextran sedimentation step. After hypotonic lysis of residual red blood cells, neutrophils were resuspended in Hanks' balanced salt solution (HBSS) and evaluated in chemotaxis assays.

\section{Chemotaxis assay}

Following neutrophil isolation, cells were fluorescein-labeled with BCECF (2', 7'-bis [2carboxyethyl]-5-[and 6]-carboxy-fluorescein acetoxymethyl ester) (Molecular Probes, Inc., Eugene, Ore.) for $30 \mathrm{~min}$ at $37^{\circ} \mathrm{C}$. After a washing step, labeled cells $\left(5 \times 10^{6} \mathrm{cells} / \mathrm{ml}\right)$ were loaded into the upper chamber of a 96-well mini chamber (NeuroProbe, Inc., Gaithersburg, Md.), separated by a polycarbonate filter with a porosity of $3 \mu \mathrm{m}$ (NeuroProbe). The lower chambers were loaded with different concentrations of C5a in presence or absence of the different anti-C5a antibodies $(10 \mu \mathrm{g} / \mathrm{ml})$. Cells were then incubated for $30 \mathrm{~min}$ at $37^{\circ} \mathrm{C}$. The number of neutrophils migrating through the polycarbonate membrane to the lower surface was determined by cytofluorometry (Cytofluor II, PerSeptive Biosystems, Inc., Framingham, Mass.). For each condition, samples were set up and measured at least in quadruplicate.

\section{Hemolytic complement assay}

We assessed the ability of the different anti-C5a antibodies to inhibit serum complement activityby measuring the hemolytic activity of fresh rat serum in presence or absence of these antibodies. Briefly, rat serum from control rats was serially diluted in TBS (75g/l NaCl, $177 \mathrm{ml} / 1$ $1 \mathrm{~N} \mathrm{HCl}, 28 \mathrm{ml} / 1$ Triethanolamine, $1.2 \mathrm{ml} / 1$ 1.25 $\mathrm{M} \mathrm{CaCl}_{2}, 1.2 \mathrm{ml} / 14.16 \mathrm{M} \mathrm{MgCl}_{2}$ ) and the dilution causing $25 \%$ lysis of sensitized sheep red blood cells (Colorado Serum Company, Denver, Colo.) after incubation at $37^{\circ} \mathrm{C}$ for $60 \mathrm{~min}$ was determined. To this dilution of rat serum, either preimmune $\operatorname{IgG}(1-50 \mu \mathrm{g} / \mathrm{ml})$ or the different anti-C5a (A, M, and C) antibodies in a final concentration of $1-50 \mu \mathrm{g} / \mathrm{ml}$ were added and incubated at $37^{\circ} \mathrm{C}$ for $1 \mathrm{~h}$. The complement reaction was stopped by adding ice-cold TBS (with $0.05 \%$ gelatin) followed by a centrifugation step (2500 x g, $5 \mathrm{~min}$ ). Absorbance of the supernatant (at $541 \mathrm{~nm}$ ) was measured and the hemolytic activity of rat serum in presence or absence of the indicated antibodies was determined in the standard manner (25). 


\section{Cecal ligation puncture (CLP)}

We used male Long Evans specific pathogen-free male rats (Harlan, Inc., Indianapolis, Ind.), weighing 275-300 g in all experiments. Rats were anesthetized by intraperitoneal injection of ketamine $(20 \mathrm{mg} / 100 \mathrm{~g}$ body weight). A $2-\mathrm{cm}$ long midline incision was made, sufficient to expose the cecum and adjoining intestine. With 4-0 silk suture, the cecum was tightly ligated below the ileocecal valve without causing bowel obstruction and then punctured through and through with a 21-gauge needle. It was gently squeezed to extrude luminal content and to ensure patency of the two puncture holes. The abdominal incision was then closed with 4-0 nylon suture and skin metallic clips (Ethicon, Inc., Somerville, N.Y.). Sham-operated animals underwent the same procedure except for ligation and puncture of the cecum. Immediately after CLP $(0 \mathrm{~h})$ or at given delayed timepoints $(6,12$, or $24 \mathrm{~h}$ after CLP), animals received either preimmune IgG or anti-C5a peptide $\mathrm{Ab}$ to the $\mathrm{A}, \mathrm{M}$, or $\mathrm{C}$ region at indicated doses, ranging from $200 \mu \mathrm{g}$ to 600 $\mu \mathrm{g} / \mathrm{animal}$. Before and after surgery, rats had unrestricted access to food and water. Survival rates were determined over a 10-day period, with assessment every $6 \mathrm{~h}$.

For pharmacokinetic studies, a carotid artery catheter (PE-50, Becton-Dickinson Colo., Sparks, Md.) was placed in some animals prior to surgery through an anterior cervical incision followed by subcutaneous tunneling and externalization in the posterior cervical area.

\section{Pharmacokinetic studies}

To evaluate the pharmacokinetic pattern (blood clearance) of anti-C5a IgG and its control IgG during sepsis, anti-C5a peptide $\mathrm{Ab}$ to the $\mathrm{M}$ region and preimmune $\mathrm{IgG}$ were labeled with ${ }^{125} \mathrm{I}$ by using the chloramine T-based method as described (26). Control animals and CLP-animals were injected with $400 \mu \mathrm{g}$ of either anti-C5a M antibody or preimmune IgG with trace amounts of

${ }^{125} \mathrm{I}$-anti-C5a $(4 \mu \mathrm{g}$, specific activity $12.97 \mu \mathrm{Ci} / \mu \mathrm{g})$ or ${ }^{125} \mathrm{I}$-preimmune $\mathrm{IgG}$ ( $4 \mu \mathrm{g}$, specific activity $16.89 \mu \mathrm{Ci} / \mu \mathrm{g})$, respectively. Immediately after CLP and subsequent administration of the labeled antibodies, small aliquots of blood $(20 \mu \mathrm{l})$ were drawn via the carotid artery catheter at indicated timepoints $(1,5,10,15,30,60,360,720 \mathrm{~min})$ and equal volumes of sterile physiological $\mathrm{NaCl}-$ solution reinjected to maintain blood volume. The radioactivity of blood samples was measured in a gamma counter (1261 Multigamma, EG\&G, Wallac, Gaithersburg, Md.) and normalized to the 1 min timepoint value to evaluate the blood clearance of anti-C5a and preimmune IgG. Data were fitted to a biphasic nonlinear regression plot by using Graph Pad Software (Prism 3.0, Graph Pad Software, Inc., San Diego, Calif.).

\section{Statistical analyses}

All values were expressed as mean \pm SE. Results were considered statistically significant where $p$ $<0.05$. For analysis of survival curves, log rank and $-2 \log$ rank tests were used. Outcomes in different treatment groups were compared by using Chi-square and Fisher's exact tests. Data sets of chemotaxis were analyzed with one-way ANOVA; differences in the mean values among experimental groups were then compared by using the Tukey multiple comparison test. Statistical significance for the pharmacokinetics data was determined by a Student's $t$-test.

\section{RESULTS}




\section{Characterization of anti-C5a peptide antibodies}

The regions of rat C5a selected for synthesis of peptides and subsequent antibody production are shown in Figure 1. The A peptide region (residues 1-16), the M peptide region (residues 17-36), and the $\mathrm{C}$ peptide region (residues 58-77) were selected for antibody production and evaluation of their relative protective effects. The deduced NMR structure of rat C5a indicating the positions of the different peptides is shown in this figure, assuming that the helical structure of rat $\mathrm{C} 5 \mathrm{a}$ is similar to the configuration of human and porcine $\mathrm{C5a}$ (27). To determine the specificity of the three different anti-C5a peptide antibodies A, M, and C, a Western blot was performed where rrat C5a (200 ng) and rhuman C5a (200 ng) were electrophoresed in a 15\% SDS-PAGE gel. All three antibodies detected rrat $\mathrm{C} 5 \mathrm{a}(\mathrm{C}>\mathrm{M}>\mathrm{A})$, but none recognized human C5a (Fig. 2) despite the high degree of homology of rat and human C5a (>68\%) (28). These antibodies could also detect $\mathrm{C} 5 \mathrm{a}$ in activated rat serum but not in activated human serum (data not shown).

\section{Effects of anti-C5a A, M, and C antibodies on rrat C5a chemotactic activity}

To assess in vitro the effects of the various anti-C5a peptide antibodies on chemotactic responses of neutrophils, the experiments were done with rrat $\mathrm{C} 5 \mathrm{a}$ in the absence or presence of these antibodies $(10 \mu \mathrm{g} / \mathrm{ml})$. Rat neutrophils exposed to rrat C5a (ranging from $0.1 \mathrm{pM}$ to $1,000 \mathrm{nM}$ ) showed a typical dose-dependent chemotactic response, peaking between 10 and $100 \mathrm{nM}$ of rrat C5a (Fig. 3, inset). When $10 \mathrm{nM}$ rrat C5a was preincubated with $10 \mu \mathrm{g} / \mathrm{ml}$ preimmune IgG, no inhibition of the chemotactic activity for neutrophils was observed (data not shown). While the presence of the various anti-C5a antibody preparations alone $(10 \mu \mathrm{g} / \mathrm{ml})$ did not evoke a significant chemotactic response, preincubation of rat $\mathrm{C} 5 \mathrm{a}$ with anti-C5a $\mathrm{M}$ or $\mathrm{C}$ antibodies significantly inhibited the C5a-induced neutrophil response (67\% and 82\%, respectively) (Fig. 3). Pretreatment of rrat C5a with anti-C5a A only slightly decreased the chemotactic activity of neutrophils but not in a statistically significant manner $(25 \%, p>0.05)$. These data indicate varying degrees of blockade of C5a chemotactic activity as a function of the antibody used (in a descending order of efficacy: $\mathrm{C}>\mathrm{M}>>\mathrm{A}$ ). These findings roughly parallel the in vivo efficacy of these antibody preparations (described below).

\section{Lack of inhibition by anti-C5a antibodies on hemolytic activity of rat serum}

To assess the extent to which anti-C5a preparations (anti-C5a $\mathrm{M}$ or $\mathrm{C}$ ) might interfere with the hemolytic activity of rat serum and assembly of C5b-9 (MAC), whole hemolytic activity was measured in presence or absence of these antibodies. There were no significant differences in hemolysis of sensitized sheep erythrocytes in the presence of fresh rat serum containing preimmune IgG or anti-C5a M or C antibodies at concentrations of 10-25 $\mu \mathrm{g} / \mathrm{ml}$ (Fig. 4). Modest inhibition was found at the concentration of $50 \mu \mathrm{g} / \mathrm{ml}$. As we describe below, the measured antiC5a antibody concentration in whole blood $6 \mathrm{~h}$ after induction of sepsis was less than $40 \%$ of the administered amount. It can be calculated that the highest serum concentration of rabbit $\operatorname{IgG}$ in rats receiving $400 \mu \mathrm{g}$ rabbit $\mathrm{IgG}$ would be $<25 \mu \mathrm{g} / \mathrm{ml}$ serum at the injection time and $<10 \mu \mathrm{g} / \mathrm{ml}$ $6 \mathrm{~h}$ after CLP, respectively. Accordingly, various rabbit IgG preparations were added to rat serum to achieve concentrations in a similar range and a range above this concentration. As 
shown in Figure 4, at preimmune IgG concentrations of 10 or $25 \mu \mathrm{g} / \mathrm{ml}$, no significant changes in hemolytic serum activity were detectable. At a concentration of $50 \mu \mathrm{g} / \mathrm{ml}$, the $\mathrm{M}$ and $\mathrm{C}$ antibody preparations reduced hemolytic activity by less than $16 \%$ or $10 \%$, respectively. At the assumed in vivo concentration of anti-C5a $(<25 \mu \mathrm{g} / \mathrm{ml}$ blood $)$ in the present CLP sepsis model, it can be predicted that there would be no significant interference with the hemolytic activity of rat serum ( $<8 \%$ for anti-C5a M $<4 \%$ for anti-C5a C at $25 \mu \mathrm{g} / \mathrm{ml}$, and $<1 \%$ for both antibodies at 10 $\mu \mathrm{g} / \mathrm{ml})$. These data suggest that at the expected plasma concentration of the infused $400 \mu \mathrm{g} \operatorname{IgG}$, there would be minimal or no effects on the hemolytic activity of rat serum.

\section{Protective effects of $\mathrm{A}, \mathrm{M}$, and $\mathrm{C}$ peptide antibodies in the CLP model}

Rats with CLP-induced sepsis received intravenously either $400 \mu \mathrm{g}$ preimmune IgG immediately after the CLP procedure or $400 \mu \mathrm{g}$ IgG antibody against A, M, or C peptides regions of rat C5a. Survival of rats was assessed during a 10-day period (Fig. 5). In sham-operated groups, which underwent the same surgical procedure minus the cecal ligation and puncture, all animals survived the 10-day interval $(n=10)$. Twenty-four hours after CLP, survival of the preimmune IgG-treated rats with sepsis was 50\% (15 of 30). After 1 day, however, both the anti-C5a A and anti-C5a M peptide-treated groups showed $80 \%$ survival 1 day after CLP ( 8 of 10), and no CLP animal died during the first $24 \mathrm{~h}$ in the anti-C5a $\mathrm{C}$ peptide-treated group. Subsequently, the survival of the preimmune IgG and anti-C5a A peptide treatment groups diminished progressively each day until day 6.5, to $20 \%$ (6 of 30) and 30\% (3 of 10), respectively. At the end of the 10-day interval these mortality rates remained the same in the two groups. In the antiC5a M peptide or anti-C5a C peptide-treated groups 2 days after CLP, 60\% (6 of 10) and 70\% (7 of 10) of the animals, respectively, survived. The difference between the 10-day outcome of antiC5a $\mathrm{M}$ peptide or $\mathrm{C}$ peptide groups and the anti-C5a A peptide or preimmune IgG-treated CLP groups was statistically significant ( $p<0.03$ for anti-C5a M vs. pre IgG, and $p<0.05$ for anti-C5a $\mathrm{C}$ vs. pre IgG, respectively), which suggests substantially improved survival rates during sepsis by administration of antibodies targeting the $\mathrm{M}$ or $\mathrm{C}$ regions of $\mathrm{C5}$.

\section{Pharmacokinetic patterns of antibody clearance from blood}

The pharmacokinetics of anti-C5a M peptide antibody or preimmune IgG in rats with or without CLP-induced sepsis after a single intravenous bolus of $400 \mu \mathrm{g}$ Ab together with trace amounts of

${ }^{125}$ I-labeled $\mathrm{Ab}$ are shown in Figure 6. A biphasic decline in whole blood concentrations was observed for all experimental conditions. The early distribution phase was characterized by a mean half-life of approximately $15 \mathrm{~min}$, whereas the dominant and latter phase of elimination demonstrated a mean half-life of $7.2 \mathrm{~h}$. The blood clearance in the elimination phase revealed a significantly reduced half-life for anti-C5a M peptide antibody in CLP animals of $5.0 \mathrm{~h}$ compared with control animals of $7.0 \mathrm{~h}$. Preimmune $\mathrm{IgG}$ treated animals demonstrated a prolonged clearance of antibody of $7.8 \mathrm{~h}$ in CLP-rats, whereas control rats showed a clearance rate of $8.1 \mathrm{~h}$. These data are consistent with the interpretation that accelerated clearance of antiC5a in CLP animals is caused by formation of C5a-anti-C5a complexes, which would be expected to be rapidly cleared from the circulation.

\section{In vivo dose responses for protective effects of anti-C5a $\mathrm{A}, \mathrm{M}$, and $\mathrm{C}$ peptide antibodies}


Antibody amounts ranging from 200 to $600 \mu \mathrm{g}$ /animal were infused just after CLP. As shown in Table 1, the greatest survival rates $(>80 \%)$ were found at the $600 \mu \mathrm{g}$ dose of anti-C5a M or C peptide antibodies. At a dose of $600 \mu \mathrm{g}$, treatment with anti-C5a A peptide antibody showed no significant improvement in survival (20\%, 2 of 10) compared with the pre IgG group (23\%, 5 of 22). Injection of higher doses (up to $1000 \mu \mathrm{g} / \mathrm{animal}$ ) did not produce greater survival rates (data not shown). These data indicate dose-dependent protective effects against the lethal complications of sepsis in CLP animals when antibodies to the $\mathrm{M}$ and $\mathrm{C}$ regions of rat C5a were used.

\section{Protective effects of delayed infusion of anti-C5a $\mathrm{M}$ or $\mathrm{C}$ antibodies during sepsis}

To determine if delayed infusion of antibodies can still confer protective effects in vivo after CLP, $600 \mu \mathrm{g}$ of the most protective antibodies (anti-C5a M and C) were infused intravenously 6, 12, or $24 \mathrm{~h}$ after onset of CLP. When infused immediately after CLP ( $0 \mathrm{~h}, \underline{\text { Fig. 7A }})$, anti-C5a Mor C-treated groups exhibited highly protective effects (leading to $>80 \%$ survival), with no death occurring after 1.5 days. When infusion was delayed until $6 \mathrm{~h}$ after CLP (Fig. 7B), both antibodies still conferred significant protection $(p<0.03)$ even though aerobic and anaerobic bacteria were detectable in blood samples at this timepoint $(20 \pm 6$ colony forming units $/ \mathrm{ml}$ blood, data not shown). At $12 \mathrm{~h}$ after CLP, the majority of animals exhibited typical clinical signs of sepsis: decreased physical activity, piloerection, cessation of grooming behavior, glazed eyes with crusting exudates, tachypnea, and reduced urinary output (24). Infusion of anti-C5a M and anti-C5a C (600 $\mu \mathrm{g} / \mathrm{animal})$ again significantly improved survival at 10 days [37\% (9 of 24) for anti-C5a M, 46\% (11 of 24) for anti-C5a C $(p<0.05)$ ] as compared with the preimmune IgGtreated group [12\% (3 of 24)] (Fig. 7C). The protective effects of the anti-C5a M and C peptide antibodies were lost, if infusion was delayed until $24 \mathrm{~h}$ after CLP (data not shown). Although the anti-C5a protective effects diminished with elapsed time of infusion, these data suggest that delayed infusion of anti-C5a, even in the presence of overt clinical signs of sepsis, confers protective effects.

\section{DISCUSSION}

An abundance of evidence suggests that during sepsis, homeostatic control of the inflammatory system has been lost (1-4, 15-18). In experimental sepsis induced by CLP, we have recently demonstrated in rats that extensive complement activation occurs, leading to C5a deposition on blood neutrophils and a loss of the respiratory burst in those cells, resulting in defective bacterial killing and a high mortality rate (12). Blockade of C5a using an antibody to the middle peptide region (M) of rat $\mathrm{C} 5$ a caused protective effects during sepsis. To establish the most protective anti-C5a antibody as well as the dose of anti-C5a that provides optimal protection against the lethal effects of sepsis, we raised polyclonal antibodies against different peptide regions of the rat $\mathrm{C} 5$ a molecule (Figs. 1, 2, $\underline{4}$ ). Whereas IgG antibodies targeting the amino-terminal residues 116 (A region of $\mathrm{C} 5 \mathrm{a}$ ) did not prevent the lethal consequences of experimental sepsis, antibodies against the middle core residues 17-36 of the $\mathrm{M}$ region or against the carboxyl-terminal residues 58-77 (C region) greatly improved survival of CLP-rats in a dose-dependent manner (Fig. 5, Table 1). In earlier sepsis models with infusion of large amounts of LPS or live bacteria, pretreatment with polyclonal antibodies against whole rat C5a were shown to reduce the LPSinduced systemic hypotension in rats (21), and antibodies against human $\mathrm{C} 5 \mathrm{a}_{\mathrm{des}}$ arg have been 
reported to attenuate signs of septic shock and associated respiratory dysfunction in monkeys $(15,22)$. More recent studies, using a neutralizing monoclonal antibody against the C-terminal 57-74 amino residues of porcine C5a demonstrated improved oxygen utilization (18) and reduced IL-6 synthesis (23) after intravenous infusion of live E. coli into pigs. Similarly, two different types of synthetic peptides that bind to C5aR have been demonstrated to be powerful $\mathrm{C} 5 \mathrm{aR}$ antagonists in vitro and have resulted in reduced neutrophil influx into tissues of mice in vivo. Protective effects against ischemia-reperfusion injury were found in mice (29) and in acute endotoxemia in rats (30). These reports support our findings that the $\mathrm{C}$ terminal region is a useful target for antibody blockade, which leads to improved survival during sepsis (Fig. 5). Short Cterminal peptides of $\mathrm{C} 3 \mathrm{a}$ anaphylatoxin can induce functional responses that are equivalent to the activity of the full C3a molecule (31). In contrast, C-terminal peptides of C5a have little, if any, of the agonist activity of the whole $\mathrm{C} 5 \mathrm{a}(27,32,33)$, which suggests that amino acids in addition to the final C-terminal 21 amino acids are required to elicit full functional activity. In human C5a, the region between Lys-20 and Arg-37, and particularly the area around Cys-27, have been postulated to be major antigenic domains of C5a (34). This is again in accord with our current finding of greatly protective effects during sepsis by blockade of the $\mathrm{M}$ region or the $\mathrm{C}$ terminal region of C5a. These data are also consistent with the idea that multiple discontinuous regions of C5a interact with multiple discontinuous regions of the C5aR $(32,35,36)$. Accordingly, it can be inferred that blockade of different regions of C5a can effectively block biological function of the molecule. Blockade of any of these regions interferes with interaction of C5a with C5aR, affecting signal-transduction. Although the amino-terminal helix of C5a somehow contributes to the full potency of the intact C5a molecule (37-39) and serves to stabilize a biologically favorable C5a conformation (32), it is not an essential component of the active site of C5a (33, $38,40)$. Our in vivo studies imply that the N-terminal residues 1-16 are not good targets for antibodies that can lead to protective effects in CLP-induced sepsis.

During the early systemic inflammatory response in sepsis associated with elevated plasma levels of $\mathrm{C} 3 \mathrm{a}$ and $\mathrm{C} 5 \mathrm{a}(7-9,41)$, changes in neutrophils have been described, characterized by increased enzyme release and enhanced chemotactic activity $(42,43)$. As sepsis progresses, this results in global deactivation of neutrophils resulting in loss of functional responsiveness to C5a, and formyl chemotactic peptide $(42,43)$, and defective bacterial killing (12). Injection of C5a or LPS into rats has been shown to mimic some features of sepsis, including hypotension, neutropenia, and elevated TNF- $\alpha$ serum levels $(21,30)$. C5a or LPS-induced neutropenia (44) and defective neutrophil chemotactic migration in vitro have been attenuated by pretreatment of animals with small $\mathrm{C} 5 \mathrm{aR}$ antagonists containing substituted amino acids in the C-terminal sequence of C5a $(30,45)$. In the present study, antibodies against different peptide regions of C5a suppressed the chemotactic activity of rat neutrophils to rat $\mathrm{C} 5 \mathrm{a}$ in a descending order of potency: $\mathrm{C} \geq \mathrm{M} \gg>\mathrm{A}$ (Fig. 3), which mirrors the protective in vivo effects of these antibodies. Because both recruitment and activation of neutrophils during sepsis are essential for direct or remote organ injury (46), effective blockade of the chemotactic activity by anti-C5a antibodies preserves vital protective functional responses of neutrophils, resulting in less organ injury and improved survival.

After in vitro and in vivo investigation of the most effective antibody preparations and the optimal doses of those antibodies (Table 1), pharmacokinetic studies were performed to determine in vivo the circulating antibody concentration over time after induction of sepsis. After an initial rapid distribution phase $(\leq 1 \mathrm{~h})$, most likely due to vascular equilibration (47), a slower 
phase of elimination was observed with a shorter half-life of anti-rat C5a M IgG compared with preimmune IgG in CLP rats (Fig. 6). At later timepoints, the relatively faster clearance rate of the anti-C5a $\mathrm{M}$ antibody in rats with sepsis may be due to the ability of anti-C5a (but not preimmune $\mathrm{IgG}$ ) to form immune complexes with C5a generated during sepsis $(2,3,8-10)$, followed by an accelerated removal of the in vivo generated immune complexes by the monocyte-phagocytic system. A rapid, C3b-dependent clearing mechanism for IgG immune complexes (IC) has been described in primates: IC became rapidly bound to erythrocytes via their CR1 content and 5 min later were rapidly removed as they transversed the liver (48). Inasmuch as $12 \mathrm{~h}$ after CLP more than two-thirds of the initially injected anti-C5a antibodies are eliminated from the circulation, (Fig. 6), it is essential to know how long after onset of CLP-induced sepsis anti-C5a preparations are still able to protect against the lethal consequences of sepsis. In all reported sepsis models to date, protective anti-C5a antibodies were administered before or at the time of experimentally induced sepsis $(15,18,20,21,23)$. We have shown that injection of anti-C5a immediately after sepsis-induction also protects against its detrimental effects (12). The present data suggest, however, that even after a considerable delay (6-12 h) in administering antibodies, which were targeted against the $\mathrm{M}$ or $\mathrm{C}$ terminal regions of $\mathrm{C} 5 \mathrm{a}$, there was still a significant improvement of survival (Fig. 7). In the CLP model, a relatively rapid development of polymicrobial sepsis within the first $12 \mathrm{~h}$ and subsequent lethal complications occurs $(12,24)$, characterized by an early hyperdynamic phase (2-10 h after CLP), followed by a late hypodynamic phase (after $16 \mathrm{~h}$ or later) (49). The hyperdynamic phase of sepsis is compressed in the CLP model in rats to a rather brief period $(<16 \mathrm{~h}$ ) relative to that in humans, which often appears to extend over 3 days (50). The data in the rat model suggest that anti-C5a intervention is effective during the hyperdynamic phase, although the protective effects diminish with time (Fig. 7). These data implicate that, in humans with sepsis, there may be a 'window' of time of several days during which such an intervention may be useful.

\section{ACKNOWLEDGMENTS}

This work was supported by a grant from the National Institutes of Health, GM-29507 and GM31963. We thank Ms. F.A. Bjork and Dr. D. McConnell for radiolabeling of antibodies and Dr. J. Maybaum (Dept. of Pharmacology, University of Michigan) for his help in the pharmacokinetic studies. We also thank Ms. Beverly Schumann and Ms. Peggy Otto for their excellent secretarial assistance in preparation of the manuscript.

\section{REFERENCES}

1. McCabe, W. R. (1973) Serum complement levels in bacteremia due to gram negative organisms. N. Engl. J. Med. 288, 21-23

2. Hecke, F., Schmidt, U., Kola, A., Bautsch, W., Klos, A., and Köhl, J. (1997) Circulating complement proteins in multiple trauma patients-correlation with injury severity, development of sepsis, and outcome. Crit. Care Med. 25, 2015-2024

3. Stöve, S., Welte T., Wagner, T.O.F., Kola, A., Klos, A., Bautsch, W., and Köhl, J. (1996) Circulating complement proteins in patients with sepsis or systemic inflammatory response syndrome. Clin. Diagn. Lab. Immunol. 3, 175-183 
4. Kapur, M. M., Jain, P., and Gidh, M. (1986) The effect of trauma on serum C3 activation and its correlation with injury severity score in man. J. Trauma 26, 464-466

5. Sharma, V. K., Agarwal, D. S., and Satyanand Saha, K. (1980) Profile of complement components in patients with severe burns. J. Trauma 20, 976-978

6. Heideman, M., Saravis, C., and Clowes, G.H.A. (1982) Effect of non-viable tissue and abscesses on complement depletion and the development of bacteremia. J. Trauma 22, $527-532$

7. Weinburg, P. F., Matthay, M. A., Webster, R. O., Roskos, K. V., Goldstein, I. M., and Murray, J. F. (1984) Biologically active products of complement and acute lung injury in patients with the sepsis syndrome. Am. Rev. Respir. Dis. 130, 791-796

8. Bengtson, A. and Heideman, M. (1988) Anaphylatoxin formation of sepsis. Arch. Surg. 123(5), 645-649

9. Nakae, H., Endo, S., Inada, K., and Yoshida, M. (1996) Chronological changes in the complement system in sepsis. Jpn. J. Surg. 26, 225-229

10. Bengtson, A. and Heideman, M. (1986) Altered anaphylatoxin activity during induced hypoperfusion in acute and elective abdominal surgery. J. Trauma 26(7), 631-637

11. Morgan, E. L., Weigle, W. O., and Hugli, E. E. (1982) Anaphylatoxin-mediated regulation of the immune responses. J. Exp. Med. 255, 1412-1426

12. Czermak, B. J., Sarma, V., Pierson, C. L., Warner, R. L., Huber-Lang, M., Bless, N. M., Schmal, H., Friedl, H. P., and Ward, P. A. (1999) Protective effects of C5a blockade in sepsis. Nature Medicine 5, 788-792

13. Grossklaus, C., Damerau, B., Lemgo, E., and Vogt, W. (1976) Induction of platelet aggregation by the complement-derived peptides C3a and C5a. Naunyn Schmiedebergs Arch Pharmacol. 12, 71-76

14. Björk, J., Hugli, T. E., and Smedegard, G. (1985) Microvascular effects of anaphylatoxins C3a and C5a. J. Immunol 134, 1115-1119

15. Stevens, J. H., O’Hanley, P., Shapiro, J. M., Mihm, F. G., Satoh, P. S., Collins, J. A., and Raffin, T. A. (1986) Effects of anti-C5a antibodies on the adult respiratory distress syndrome in septic primates. J. Clin. Invest. 77, 1812-1816

16. Solomkin, J. S., Cotta, L. A. and Satoh, P. S. (1985) Complement activation and clearance in acute illness and injury: evidence for C5a as a cell-directed mediator of the adult respiratory distress syndrome in man. Surgery 97, 668-678 
17. Hammerschmidt, D. E., Weaver, L. J., Hudson, L. D., Craddock, P. R., and Jacob, H. S. (1980) Association of complement activation and elevated plasma-C5a with adult respiratory distress syndrome. Lancet 1(8175), 947-949

18. Mohr, M., Hopken, U., Oppermann, M., Mathes, C., Goldmann, K., Siever, S., Gotze, O., and Burchardi, H. (1998) Effects of anti-C5a monoclonal antibodies on oxygen use in a porcine model of severe sepsis. Eur. J. Clin. Invest. 28(3), 227-234

19. Olson, L. M., Moss, G. S., Baukus, O., and Das Gupta, T. K. (1985) The role of C5 in septic lung injury. Ann. Surg. 202, 771-776

20. Prodeus, A. P., Zhou, X., Maurer, M., Galli, S. J., and Caroll, M. C. (1997) Impaired mast cell-dependent natural immunity in complement C3-deficient mice. Nature 390, $172-175$

21. Smedegard, G., Cui, L., and Hugli, T. E. (1989) Endotoxin-induced shock in the rat. A role for C5a. Am. J. Pathol. 135, 489-497

22. Hangen, D. H., Stevens, J. H., Satoh, P. S., Hall, E. W., O'Hanley, P. T., and Raffin, T. A. (1989) Complement levels in septic primates treated with anti-C5a antibodies. J. Surg. Res. 46, 195-199

23. Hopken, U., Mohr, M., Struber, A., Montz, H., Burchardi, H., Gotze, O., and Oppermann, M. (1996) Inhibition of interleukin-6 synthesis in an animal model of septic shock by anti-C5a monoclonal antibodies. Eur. J. Immunol. 26(5), 1103-1109

24. Wichterman, K. A., Baue, A. E., and Chaudry, I. H. (1980) Sepsis and septic shock-a review of laboratory models and a proposal. J. Surg. Res. 29, 189-201

25. Amsterdam, E. A., Stahl, G. L., Pan, H. L., Rendig, S. V., Fletcher, M. P., and Longhur, J. C. (1995) Limitation of reperfusion injury by a monoclonal antibody to C5a during myocardial infarction in pigs. Am. J. Physiol. 268, H448-457

26. Bennett, G. L. and Horuk, R. (1997) Iodination of chemokines for use in receptor binding analysis. Methods Enzymol. 288, 134-48

27. Zuiderweg, E.R.P., Nettesheim, D. G., Mollison, K. W., and Carter, G. W. (1989) Tertiary structure of human complement component C5a in solution from nuclear magnetic resonance data. Biochem. 28, 172-185

28. Perret, J. J., Raspe, E., Vassart, G., and Parmentier, M. (1992) Cloning and functional expression of the canine anaphylatoxin C5a receptor. Biochem J. 288, 911-917

29. Heller, T., Hennecke, M., Baumann, U., Gessner, J. E., zu Vilsendorf, A. M., Baensch, M., Boulay, F., Kola, A., Klos, A., Bautsch, W., and Kohl, J. (1999) Selection of a C5a receptor antagonist from phage libraries attenuating the inflammatory response in immune complex disease and ischemia/reperfusion injury. J. Immunol. 163, 985-994 
30. Strachan, A. J., Woodruff, T. M., Haaima, G., Fairlie, D. P., and Taylor, S. M. (2000). A new small molecule $\mathrm{C} 5 \mathrm{a}$ receptor antagonist inhibits the reverse-passive Arthus reaction and endotoxin shock rats. J. Immunol. 164, 6560-6565

31. Gerardy-Schahn, R., Ambrosius, D., Saunders, D., Casaretto, M, Mittler, C., Karwawrth, G., Gorgen, S., and Bitter-Suermann, D. (1989) Characterization of C3a receptor-proteins on guinea pig platelets and human polymorphonuclear leukocytes. Eur. J. Immunol. 19, 1095-1102

32. Mollison, K. W., Mandecki, W., Zuiderweg, E.R.P., Fayer, L., Fey, T. A., Krause, R. A., Conway, R. G., Miller, L., Edalji, R. P., Shallcross, M. A., Lane, B., Fox, J. L., Greer, J., and Carter, G. W. (1989) Identification of receptor-binding residues in the inflammatory complement protein C5a by site-directed mutagenesis. Proc. Natl. Acad. Sci. USA. 86, 292-296

33. Bubeck, P., Grötzinger, J., Winkler, M., Köhl, J., Wollmer, A., Klos, A., and Bautsch, W. (1994) Site-specific mutagenesis of residues in the human C5a anaphylatoxin which are involved in possible interaction with the C5a receptor. Eur. J. Biochem. 219, 897-904

34. Johnson, R. J., Tamerus, J. D., and Chenoweth, D. E. (1987) Identification of an antigenic epitope and receptor binding domain of human C5a. J. Immunol. 138, 38563862

35. Gerard, N. P. and Gerard, C. (1991) The chemotactic receptor for human C5a anaphylatoxin. Nature 349, 614-617

36. Wetsel, R. A., Kildsgaard, J. and Haviland, D. L. (2000) Complement Anaphylatoxins $(\mathrm{C} 3 \mathrm{a}, \mathrm{C} 4 \mathrm{a}, \mathrm{C} 5 \mathrm{a})$ and their receptors $(\mathrm{C} 3 \mathrm{aR}, \mathrm{C} 5 \mathrm{aR} / \mathrm{CD} 88)$ as therapeutic targets in inflammation. In Therapeutic Interventions in the Complement System. (Lambris, J. D. and Holers, V. M. eds.) Human Press: Totowa, New Jersey; pp. 113-153

37. Greer, J. (1985) Model structure for the inflammatory protein C5a. Science 228, 10551066

38. Gerard, C., Showell, H. J., Hoeprich, JR., P. D., Hugli, T. E., and Stimler, N. P. (1985) Evidence for a role of the amino-terminal region in the biological activity of the classical anaphylatoxin, porcine C5a des-Arg-74. J. Biol. Chem. 260, 2613-2616

39. Damerau, B., Zimmermann, B., Czorniak, K., Wüstefeld, H., and Vogt, W. (1986) Role of N-terminal regions of hog C3a, C5a and C5a-desArg in their biological activities. Mol. Immunol. 23, 433-440

40. Kaneko, Y., Okada, N., Boranyi, L., Azuma, T., and Okada, H. (1995) Antagonistic peptides against human anaphylatoxin C5a. Immunology 86, 149-154 
41. Zillow, G., Sturm, J. A., Rother, U., and Kirschfink, M. (1990) Complement activation and the prognostic value of $\mathrm{C} 3 \mathrm{a}$ in patients at risk of adult respiratory distress syndrome. Clin. Exp. Immunol. 79, 151-157

42. Solomkin, J. S., Jenkins, M. K., Nelson, R. D., Chenoweth, D. and Simmons, R. L. (1981) Neutrophil dysfunction in sepsis. II. Evidence for the role of complement activation products in cellular deactivation. Surgery 90, 319-327

43. Goya, T., Morisaki, T., and Torisu, M. (1994) Immunologic assessment of host defense impairment in patients with septic multiple organ failure: relationship between complement activation and changes in neutrophil function. Surgery 115, 145-155

44. Coughlan, A. F., Hau, H., Dunlop, L. C., Berndt, M. C., and Hankock, W. W. (1994) Pselectin and platelet-activating factor mediate initial endotoxin-induced neutropenia. $J$. Exp. Med. 179, 329-334

45. Short, A, Wang, A. K., Finch, A. M., Haaima, G., Shiels, I. A., Fairlie, D. P., and Taylor, S. M. (1992) Effects of a new C5a receptor antagonist on C5a- and endotoxin-induced neutropenia in rats. Br. J. Pharmacol. 125, 551-554

46. Nagase, T., Uozumi, N., Ishii, S., Kume, K., Izumi, T., Ouchi, Y., and Shimizu, T. (2000) Acute lung injury by sepsis and acid aspiration: a key role for cytosolic phospholipase $\mathrm{A}_{2}$. Nature Immunol. 1, 42-46

47. Cornacoff, J. B., Herbert, L. A., Smead, W. L., and Vanaman, M. E. (1983) Primate erythrocyte-immune complex-clearing mechanism. J. Clin. Invest. 71, 236-247

48. Bergman, I., Burckart, G. J., Pohl, C. R., Venkataramanan, R., Barmada, M. A., Griffin, J. A., and Cheung, N. V. (1998) Pharmacokinetics of IgG and IgM anti-ganglioside antibodies in rats and monkeys after intrathecal administration. JPET 284, 111-115

49. Yang, S., Zhou, M., Koo, D. J., and Chaudry, I. H. (1999). Pentoxifylline prevents the transition from the hyperdynamic to hypodynamic response during sepsis. Am. J. Physiol. 277, H1036-H1044

50. Parrillo, J. E., Parker, M. M., Natanson, C., Suffredini, A. F., Danner, R. L., Cunnion, R. E. and Ognibene, F. P. (1990) Septic shock in humans-advances in understanding of pathogenesis, cardiovascular dysfunction, and therapy. Ann. Intern. Med. 113, 227-242

Received September 18, 2000; accepted November 9, 2000. 
Table 1

Dose-responses of Various Anti-C5a Antibodies on 10 Day Survival of CLP-Rats

\begin{tabular}{|c|c|c|c|}
\hline CLP-groups & $\begin{array}{l}\text { i.v. dosage } \\
{[\mu \mathrm{g} / \text { animal }]}\end{array}$ & $\begin{array}{c}10 \text { day survival } \\
{[\%]} \\
\text { (survivors/n) }\end{array}$ & significance \\
\hline Preimmune $\operatorname{IgG}$ & $\begin{array}{l}200 \mu \mathrm{g} \\
400 \mu \mathrm{g} \\
600 \mu \mathrm{g} \\
\end{array}$ & $\begin{array}{ll}20 & (2 / 10) \\
20 & (6 / 30) \\
23 & (5 / 22) \\
\end{array}$ & \\
\hline anti-C5a A & $\begin{array}{l}400 \mu \mathrm{g} \\
600 \mu \mathrm{g}\end{array}$ & $\begin{array}{ll}30 & (3 / 10) \\
20 & (2 / 10) \\
\end{array}$ & $\begin{array}{l}\text { n.s. } \\
\text { n.s. }\end{array}$ \\
\hline anti-C5a M & $\begin{array}{l}200 \mu \mathrm{g} \\
400 \mu \mathrm{g} \\
600 \mu \mathrm{g}\end{array}$ & $\begin{array}{ll}50 & (5 / 10) \\
60 & (6 / 10) \\
90 & (9 / 10) \\
\end{array}$ & $\begin{array}{c}\text { n.s. } \\
* \\
*\end{array}$ \\
\hline anti-C5a C & $\begin{array}{l}200 \mu \mathrm{g} \\
400 \mu \mathrm{g} \\
600 \mu \mathrm{g}\end{array}$ & $\begin{array}{lr}67 & (8 / 12) \\
70 & (7 / 10) \\
83 & (10 / 12)\end{array}$ & $\begin{array}{l}* \\
* \\
*\end{array}$ \\
\hline
\end{tabular}

${ }^{*} \mathrm{p}<0.05$ vs preimmune $\operatorname{IgG}$ group

n.s. $=$ non significant $(\mathrm{p} \geq 0.05) \mathrm{vs}$ preimmune $\mathrm{IgG}$ group 
Fig. 1

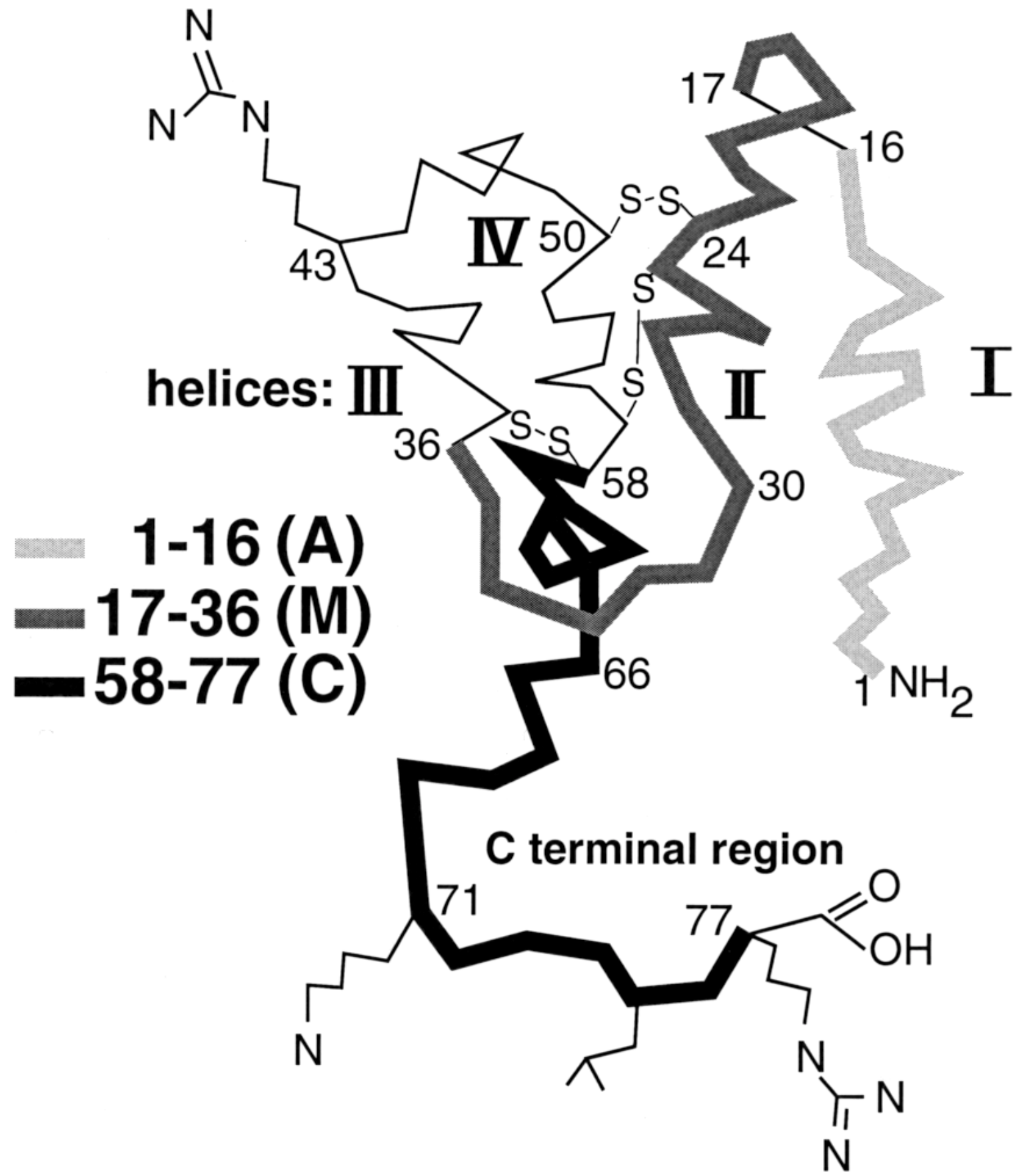

Figure 1. Location of selected peptide regions $(\mathrm{A}=$ amino-terminal, $\mathrm{M}=$ middle peptide region, and $\mathrm{C}=$ carboxyterminal region), based on the antigenic index and predicted molecular structure of rat C5a. 
Fig. 2

\section{Recombinant C5a}

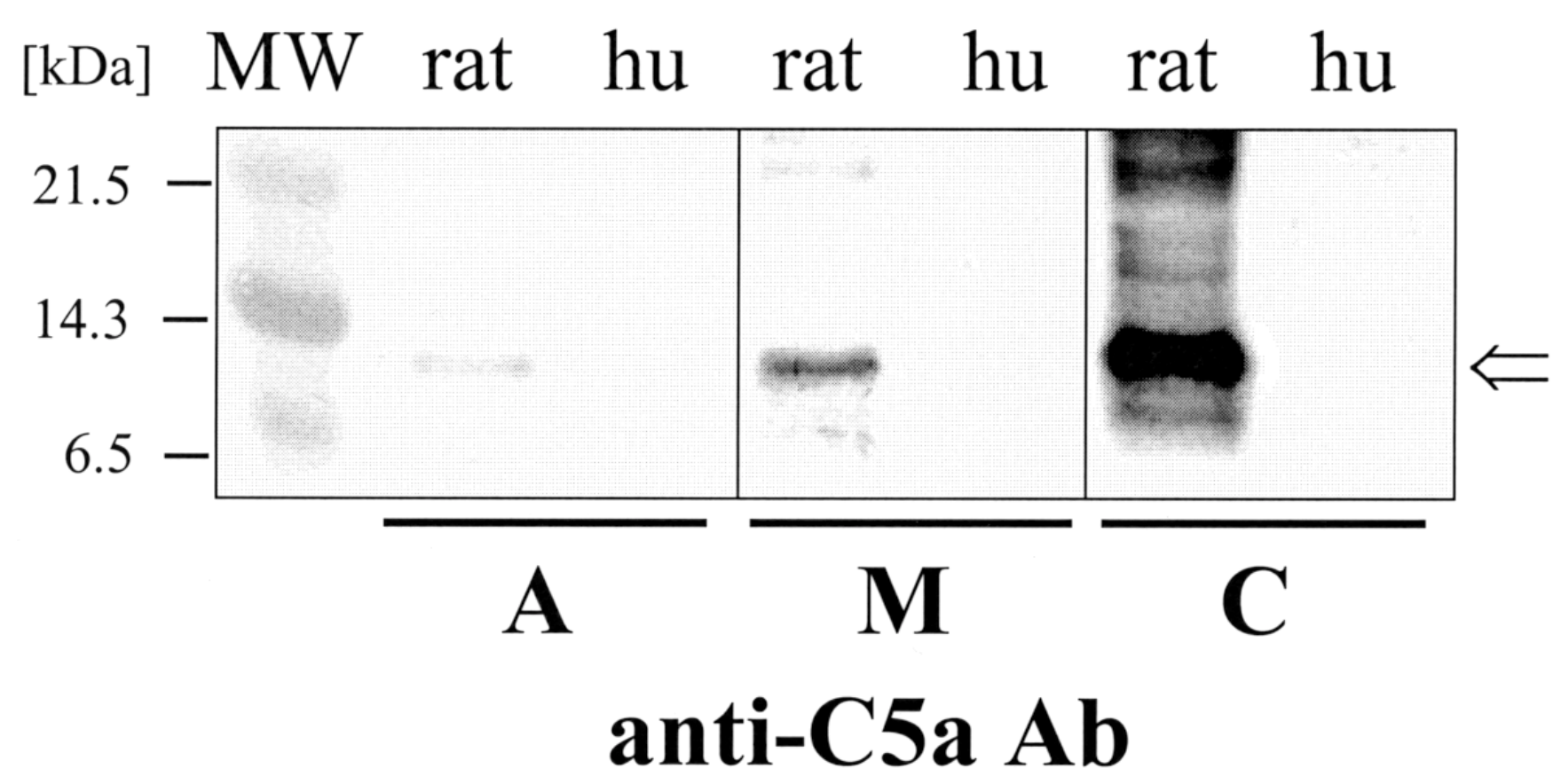

Figure 2. Western blot analysis of recombinant rat and human C5a by using IgG antibodies raised against the different regions of rat C5a (as described in legend to Fig. 1). Molecular weight marker (MW) is included. The arrow denotes expected position of recombinant, nonglycosylated C5a. 
Fig. 3
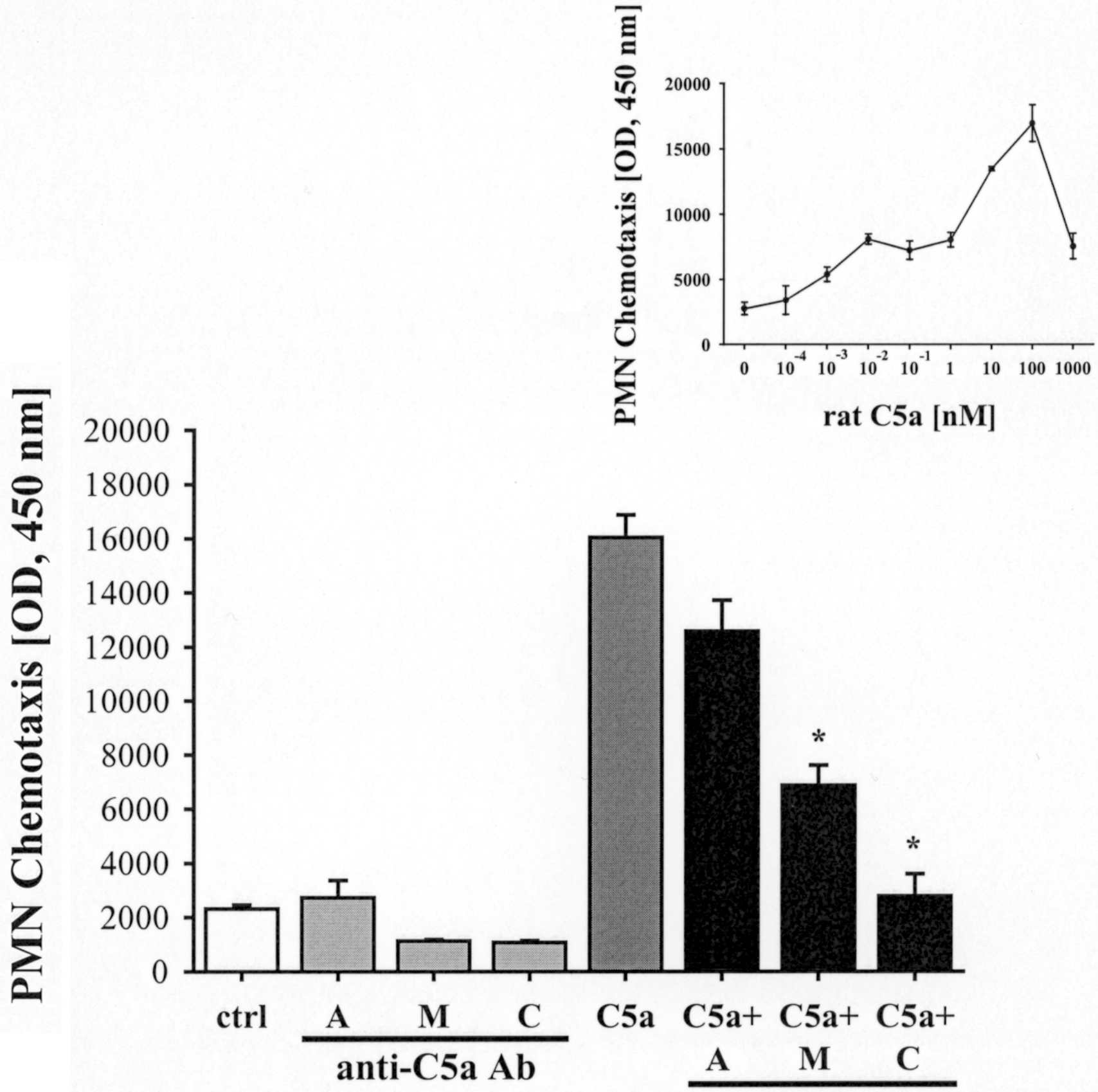

anti-C5a Ab

\section{Treatment}

Figure 3. Chemotactic responses of rat neutrophils to rrat C5a in presence or absence of anti-C5a antibodies against the amino-terminal region (A), middle peptide region (M), or carboxyl-terminal region (C) of rat C5a. Rrat C5a was used at a concentration of $10 \mathrm{nM}$ based on the dose-response curve of rat neutrophils to rrat C5a (inset). Antibodies were used at a concentration of $10 \mu \mathrm{g} / \mathrm{ml}$. 
Fig. 4

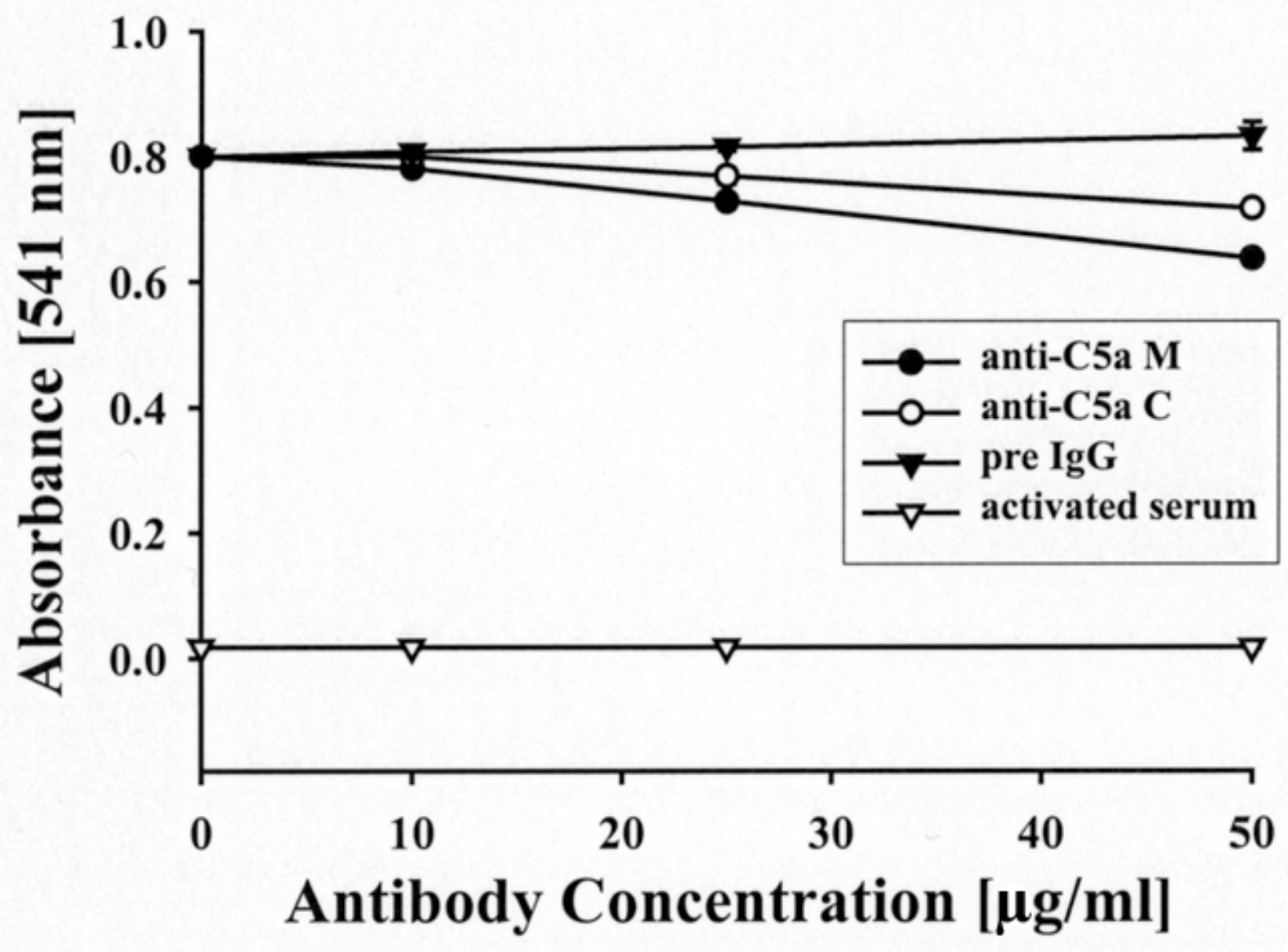

Figure 4. Hemolytic complement activity of fresh rat serum in presence of either preimmune IgG or IgG antibodies against the middle peptide region or carboxy-terminal region of $\mathrm{C} 5 \mathrm{a}$ (anti-C5a $\mathrm{M}$ or anti-C5a $\mathrm{C}$ ). 
Fig. 5

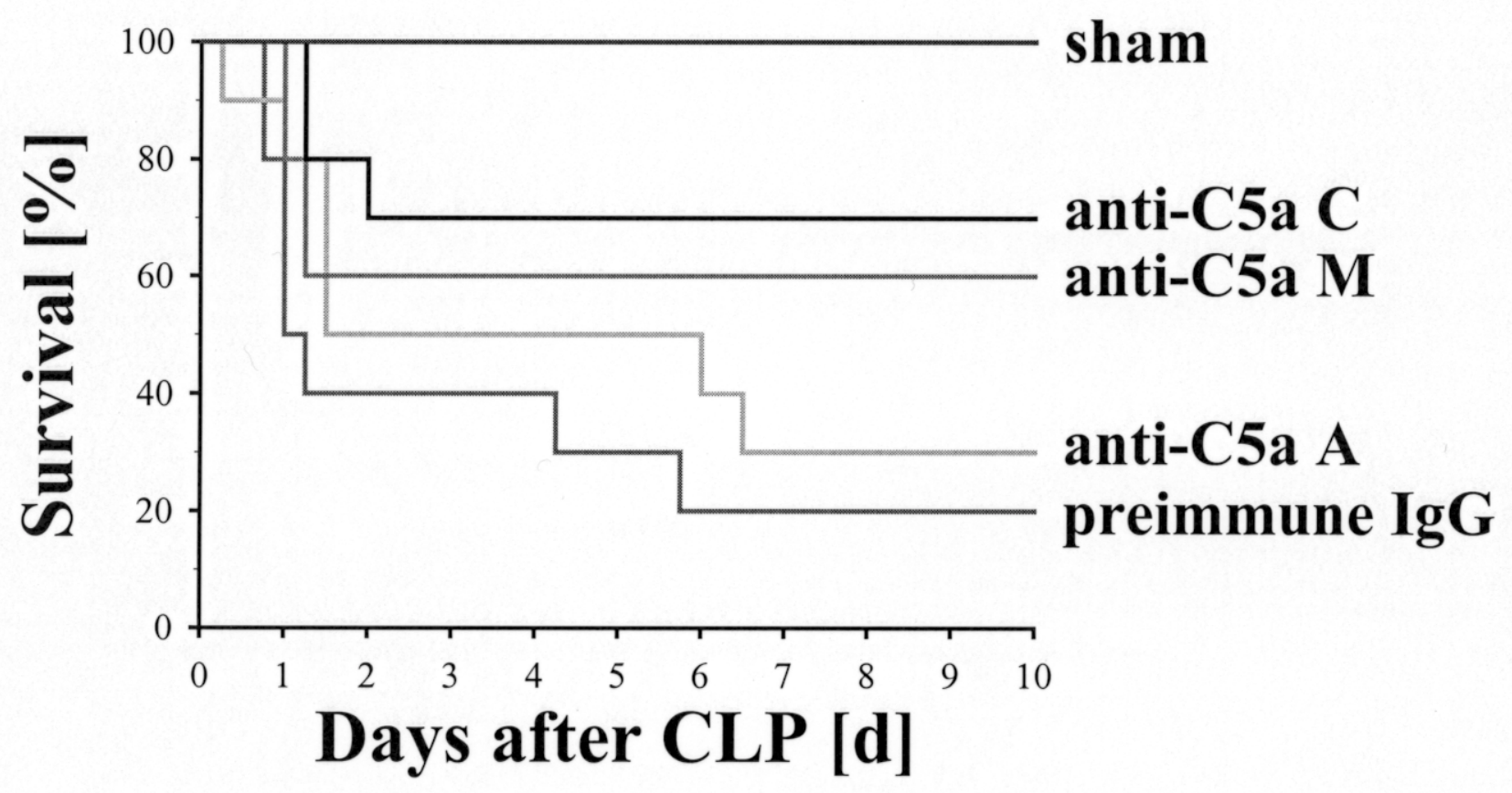

Figure 5. Survival rates of rats after CLP, as a function of treatment with either pre-immune IgG or IgG antibody against the amino-terminal region of rat $\mathrm{C} 5 \mathrm{a}$ (anti-C5a; A), the middle peptide region (anti-C5a; $\mathrm{M}$ ) or carboxyl-terminal region (anti-C5a; C) infused intravenously immediately after CLP, [400 $\mu \mathrm{g} / \mathrm{animal}$ (each group, $n=10$ )]. 
Fig. 6

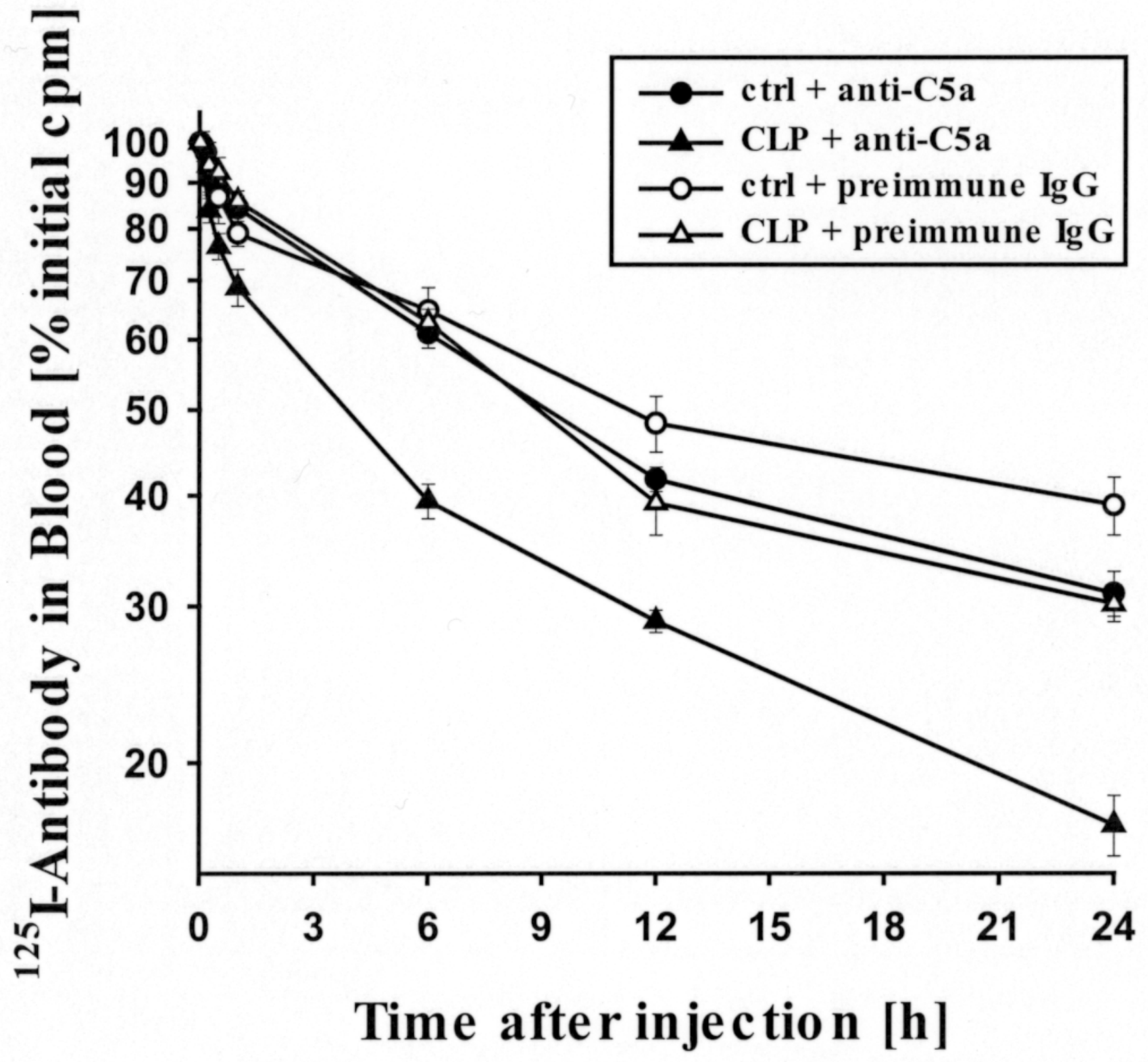

Figure 6. Blood clearance of ${ }^{125} \mathrm{I}$-anti-C5a M peptide antibody and ${ }^{125} \mathrm{I}$-preimmune IgG in rats with or without CLPinduced sepsis. Semi-logarithmic plots of blood clearance curve of ${ }^{125} \mathrm{I}$-anti-C5a M and ${ }^{125} \mathrm{I}$-preimmune $\mathrm{IgG}$ were normalized to the 1.0 min timepoint. Mean \pm SE of five animals in each group. 
Fig. 7
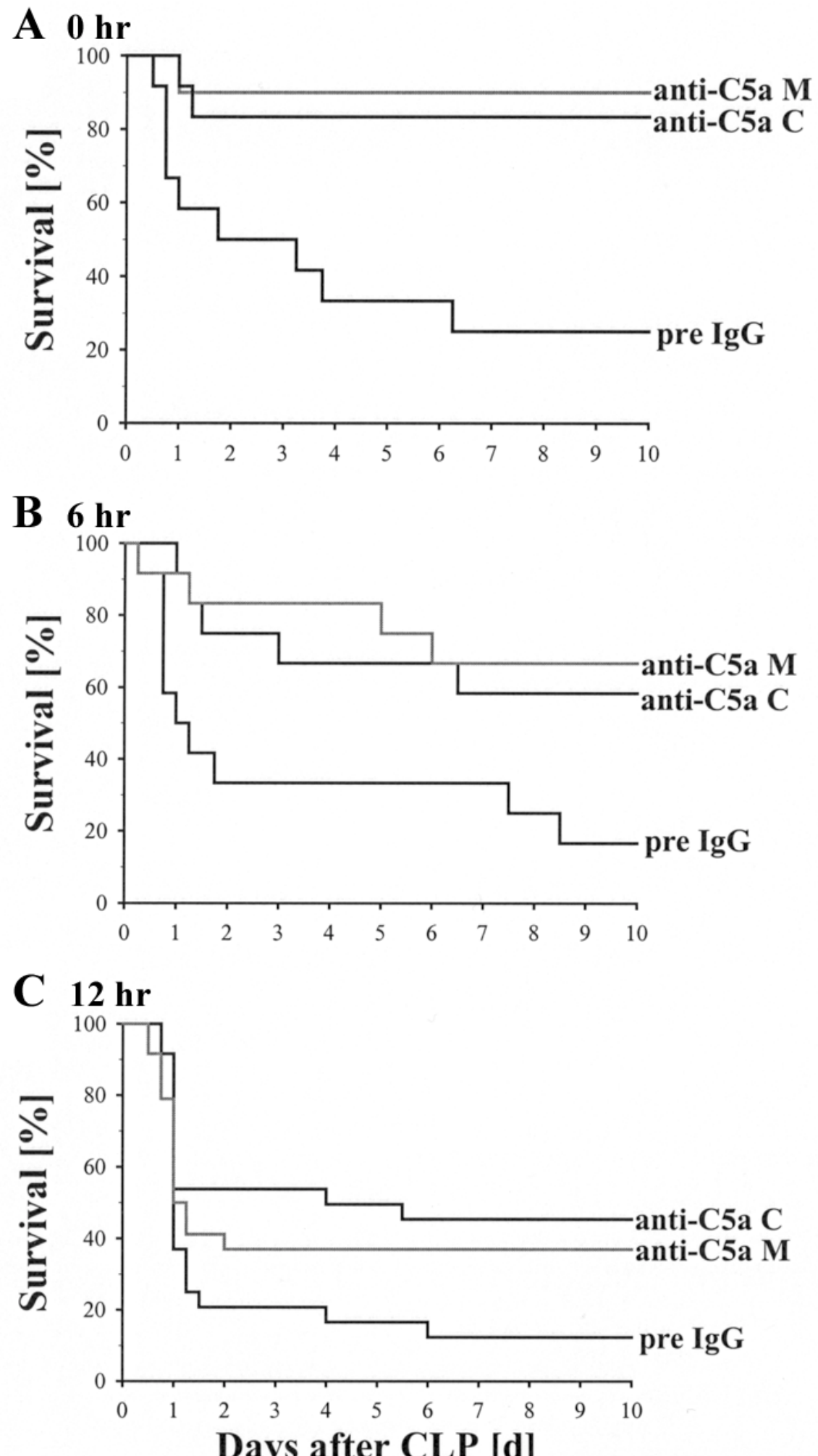

Figure 7. Ten-day survival rates of rats with sepsis and dependency on the time of intravenous infusion of anti-C5a antibodies, raised against the middle peptide region 17-36 (anti-C5a; M) or against the carboxyl-terminal region 58-77 (anti-C5a; C). Animals received either $600 \mu \mathrm{g}$ of preimmune IgG or $600 \mu \mathrm{g}$ of anti-C5a M or C, immediately after onset of CLP (A), at $6 \mathrm{~h}$ after CLP (B) or at $12 \mathrm{~h}(\mathbf{C})$. 